\title{
A comparative study of the content of heavy metals in oils: linseed oil, rapeseed oil and soybean oil in technological production processes
}

\author{
Piotr Szyczewski ${ }^{1 *}$, Marcin Frankowski ${ }^{1}$, Anetta Zioła-Frankowska², Jerzy Siepak ${ }^{3}$, \\ Tomasz Szyczewski ${ }^{4}$, Paweł Piotrowski ${ }^{4}$ \\ ${ }^{1}$ Adam Mickiewicz University Poznan, Poland \\ Department of Water and Soil Analysis \\ ${ }^{2}$ Adam Mickiewicz University Poznan, Poland \\ Department of Analytical Chemistry, \\ ${ }^{3}$ Hipolit Cegielski State College of Higher Education in Gniezno, Poland \\ ${ }^{4}$ Poznan University of Medical Sciences Poland \\ Clinic of Oral Rehabilitation
}

*Corresponding author's e-mail: p.szyczewski@gmail.com

Keywords: heavy metals, edible oils, rapeseed, soybean, linseed.

\begin{abstract}
Vegetable oils belong to a large group of substances consumed on a daily basis. World vegetable oil production is soaring, reducing the popularity of animal fats. Heavy metals pose a threat to human health. It is estimated that about $80 \%$ of the daily dose of heavy metals enters the human body through the consumption of food. Hence, it is necessary to monitor their concentrations in food products. Besides, the presence of heavy metals is thought to have possible negative influence on the quality of oils, especially on their taste and smell. Heavy metals may also accelerate the process of the rancidifiction of oils. Rapeseeds, soybean seeds and linseeds were selected for the analysis because they are one of the most popular oilseeds and at the same time they differ in terms of growing conditions. The analyses of different fractions and the ready-made product were also performed. The aim of the study was to determine the variation in concentrations of heavy metals, iron and manganese in different fractions during production. The significant concentrations of iron, manganese and zinc were observed in oilseeds. It was also shown that during different stages of oil refining the concentrations of metals decrease. The concentrations of metals are compared with those reported in literature.
\end{abstract}

\section{Introduction}

Vegetable oils are oils extracted from different parts of plants (Obiedzińska et al. 2012, Dubois et al. 2007). The most popular sources of vegetable oils include: rapeseed, sunflower, soybean, olives or sesame. World vegetable oil production is soaring, reducing the popularity of animal fats (Corley, 2009). As for their chemical make-up, vegetable oils are mixtures of saturated and unsaturated fatty acids esters. Polyunsaturated fatty acids (PUFAs) are valuable nutrients in the human diet (Krzymański 2009).

Within the group of heavy metals one can distinguish both elements that are essential for living organisms (microelements) and elements whose physiological role is unknown and thus they are "inactive" towards living organisms. Besides, metals that serve as microelements in living organisms usually occur in trace amounts precisely defined for each species. Both a shortage and an excessive concentration of such metals may have a harmful influence on living organisms, causing, among others, disorders of the nervous system due to the tendency to accumulate in tissues of the brain and liver. Reactions between heavy metals and nutrients can also cause pathological and carcinogenic effects (Angelova et al. 2005).

Determination of heavy metals in oils is a difficult analytical problem. Due to the high viscosity of oil matrix as well as difficulties in leaching and dissolving, it is necessary to develop specific analytical procedures that can ensure the reproducibility of results. The analysis that has been correctly carried out gives results used to identify possible contamination of food with micro- and macroelements.

The presence of heavy metals in vegetable oils may cause negative changes to their taste and smell. Catalytic oxidation of oils with molecular oxygen through metal ions (especially copper) leads to the so-called rancidification of oils. Metals such as aluminum and tin are characterized by low catalytic activity (Domka et al. 2010). A phenomenon termed "flavor reversion" of oils occurs in the presence of heavy metals and oxygen (Zioła-Frankowska et al. 2011). Metals such as iron, copper, chromium, zinc and cobalt in rapeseed, linseed and soybean oil undergo further reactions under the influence of visible light. (Domka et al. 2010) 
The principal source of oils contamination with heavy metals is their migration from arable soil into oil plants. Moreover, oils may be enriched with heavy metals during technological processes (Juszczak 2008).

Concentrations of heavy metals in oil plants depend on many factors, such as the plant species, soil types, anthropogenic pressure, fertilization and hydrological conditions (irrigation) (Mendila et al. 2009, Radziemska et al. 2009).

Another significant source of heavy metals is food contaminated while being processed in apparatus used during the technological-production procedure as well as vessels, containers and packaging where food is kept and transported. The intensity of assimilating heavy metals from food by the human organism is also dependent on how the plant is dealt with before it is consumed or processed. For instance washing, cleaning or technological operations such as blanching or cooking reduce the risk of becoming contaminated with heavy metals (Juszczak 2008). Additionally, raw material can also be contaminated with metals in the production process. It is therefore justified to ensure proper monitoring of the production process and to control the concentrations of heavy metals, iron and manganese at various stages of production.

\section{Aims of the study}

The aims of the study were (1) to determine the concentrations of heavy metals such as copper, zinc, cadmium, lead, iron, iron and manganese in edible oil samples including rapeseed, soybean and linseed oils, and (2) to determine the variation in heavy metals concentrations in different oil fractions.

\section{Materials and methods}

\section{Edible oil production}

In the first stage of refining oil, pressed raw oil ( $1^{\text {st }}$ fraction $)$ is obtained by grinding rapeseed and roasting the mesh, which is then humidified and conditioned. The increased temperature of the raw material is favorable for the decrease of metal content. The destruction of tissue structure allows for the first extraction of oil during hot pressing in worm presses. The byproducts of the oil processing, including its further stages, are pomace and dried distiller's grain. It should be emphasized that during the production process toxic substances - not only heavy metals - are transferred to pomace and dried distiller's grain (Radziemska et al. 2009). These, in turn, may be used in the production of fodder, posing a secondary threat to animals and through their products - to the consumer (Zioła-Frankowska et al. 2011).

The second stage - the process of oil extraction - involves its multiple rinsing from seeds using the solvent (hexane). The extraction oil $-2^{\text {nd }}$ fraction - is produced after the solvent is distilled and before de-gumming. Pressed neutral-flavored oil, which is the $3^{\text {rd }}$ fraction in the production, is marked by lower concentrations of metals in comparison to the $2^{\text {nd }}$ fraction. Obtaining this fraction involves oil hydration, removal of protein slime and phosphatides and deacidification using nitrogen hydroxide (Szyczewski et al. 2015).

Bleaching (de-coloring) - the $4^{\text {th }}$ fraction - is aimed at the removal of dyes such as chlorophyll, anthocyains and carotenoids, which give the oils their dark color. This refers especially to the chlorophyll dyes, which, apart from the dark color, accelerate oil oxidation. This process additionally removes polar substances (phospholipids and soaps) remaining after the process of deacidification. In the process of bleaching, bleaching earth oil, active carbon or aluminum oxide are used in order to absorb the given polar substances (Szyczewski et al. 2015).

The final stage of oil refining is deodorization, which gives the product its final quality of refined oil. The process removes from the oil the substances responsible for unpleasant smell and taste such as lower fatty acids, aldehydes and ketones, hydrocarbons, and sulfur compounds. The separation of the substances requires the use of distillation with water vapor under reduced pressure, as the boiling temperature of those compounds is $200-300^{\circ} \mathrm{C}$. As a result of these processes, the $5^{\text {th }}$ fraction is obtained, which is the final product ready for the consumption. (Radziemska et al. 2009)

\section{Sample preparation for analysis}

Samples obtained from the producer were stored in polyethylene bags, in a shaded place at room temperature. The analysis was performed on rapeseeds, soybean seeds and linseeds ( 0 fraction) and their fractions: pressed raw oil ( $1^{\text {st }}$ fraction $)$, extraction oil before de-gumming ( $2^{\text {nd }}$ fraction), pressed natural-flavored oil ( $3^{\text {rd }}$ fraction), pressed bleached oil ( $4^{\text {th }}$ fraction) and pressed refined oil ( $5^{\text {th }}$ fraction). Each sampling group (fractions $0-5$ ) came from the same production lot.

\section{Sample preparation}

The samples were prepared on the basis of the modified procedure contained in PN-A-86939-1:1998 and PN-92/C-04570/01, optimized as regards the research material and published by the authors (Szyczewski et al. 2015). A sample of $10 \mathrm{~g}$ was placed in a platinum melting pot and vaporized in a muffle furnace. Then the incinerated sample was dissolved in nitric acid (V) and vaporized in a muffle furnace. At the end the sample was transferred to the test-tube.

\section{Apparatus and reagents}

The concentration of heavy metals was determined using an atomic absorption spectrometer with acetylene-air flame atomization (F-AAS). A fast sequential atomic absorption spectrometer SpectrAA 20 FS (Varian, Australia) was used. The test was repeated three times for each sample.

At the sample preparation stage the following instruments were used: a muffle furnace Nabertherm L5/C6 with maximum power of $2.4 \mathrm{~kW}$, a heating panel with maximum power of $2.8 \mathrm{~kW}$, a rotation shaker designed at the Department of Water and Ground Analysis, and a magnetic mixer featuring a heating function with maximum power of $0.8 \mathrm{~kW}$.

The reagents used in the analyses were analytically pure, and the water was deionized to the resistivity of $18.2 \mathrm{M} \Omega \cdot \mathrm{cm}$ in a Direct-Q ${ }^{\circledR} 3$ Ultrapure Water System apparatus (Millipore, France). Standard solutions were prepared using Merck commercial standards for AAS (Merck, Darmstadt, Germany).

\section{Results and discussion}

The studies carried out by the authors showed that, compared to mineralization and digestion in a porcelain melting pot and to classic extraction methods, the use of a platinum melting pot for the preparation of oil samples gives the most accurate 
results (Szyczewski et al. 2015). The seeds of oil plants (and their fractions), which are characterized by different properties, were analyzed. First of all, they require different methods of cultivation and they differ in terms of seed fatty acid content and the ratio of saturated and unsaturated fatty acids (Domka et. Al. 2010). Besides, the variability in metals concentrations is related to the fact that they can occur in plants and intermediate products as metal ions or metal complexes and they can be characterized by different oxidizing activity (Juszczak 2008, Mendila et al. 2009).

Tables 1-3 present the study results for the analyzed metals in different fractions of oil refining. They are mean values taken from three tests, with a standard deviation.

The highest concentrations of each analyzed heavy metal were observed in 0 fraction. This is due to the accumulation of heavy metals in the untreated seeds. The concentrations of lead and cadmium are similar to those reported in literature (Domka et al. 2010, Saastamoinen et al. 2010). The highest concentrations - between 49.7 and 64.8 (depends on the type of seed) - were shown for iron. Relatively high concentrations were also obtained for manganese, and much lower concentrations were presented for copper and lead. The rapeseed was characterized by the highest concentrations of zinc, iron and lead, whereas the linseed by the highest concentrations of copper, manganese and cadmium. Besides, the lead concentrations shown for the five analyzed fractions were below the limit of detection.

The low concentrations of metals in each intermediate product were shown for the samples from the first stage of oil refining - pressed oil. This is the highest decrease of concentrations observed in the analyzed fractions. It is worth noticing that in these fractions toxic substances (including the analyzed metals) are transferred to pomace and dried distiller's grain (Radziemska et al. 2009). They may be used in the production of fodder and thus they may pose indirect risks to consumers (Zioła-Frankowska et al. 2011).

The oils obtained during the process of oil extraction - the $2^{\text {nd }}$ fraction - were characterized by high contamination because at this stage also other elements were extracted. Besides, higher temperature may influence the leaching of metals from the intermediate products. For these reasons the highest concentrations of cadmium and lead were observed in the $2^{\text {nd }}$ fractions. The concentrations of other analyzed heavy metals were slightly lower. The significant lower concentrations were shown for the next fractions.

The $4^{\text {th }}$ fraction - pressed bleached oil - was obtained after the process was conducted at increased temperature. As a consequence, the concentrations of copper, zinc and iron for every analyzed sample were slightly higher.

Table 1. The concentration of heavy metals in the productions fractions of rapeseed oil

\begin{tabular}{|c|c|c|c|c|c|c|c|c|c|c|c|c|}
\hline \multirow{2}{*}{ Fractions } & \multicolumn{9}{|c|}{ The concentrations of heavy metals [mg/kg] } \\
\cline { 2 - 11 } & \multicolumn{2}{|c|}{$\mathrm{Cu}$} & \multicolumn{2}{|c|}{$\mathrm{Zn}$} & \multicolumn{2}{c|}{ Mn } & \multicolumn{2}{c|}{$\mathrm{Fe}$} & \multicolumn{3}{c|}{$\mathrm{Pb}$} & \multicolumn{2}{c|}{$\mathrm{Cd}$} \\
\hline 0 & 0,76 & \pm 0.03 & 24.84 & \pm 0.36 & 22,04 & \pm 0.32 & 64,82 & \pm 1.06 & 1,43 & \pm 0.06 & 0,31 & \pm 0.03 \\
1 & 0.38 & \pm 0.02 & 1.74 & \pm 0.07 & 0.47 & \pm 0.03 & 3.25 & \pm 0.14 & $<0.06$ & \pm 0 & 0.07 & \pm 0 \\
2 & 0.10 & \pm 0.01 & 1.41 & \pm 0.05 & 0.5 & \pm 0.03 & 0.63 & \pm 0.04 & 0.21 & \pm 0.02 & 0.09 & \pm 0.01 \\
3 & 0.06 & \pm 0 & 0.45 & \pm 0.03 & $<0.12$ & \pm 0 & 2.01 & \pm 0.11 & 0.20 & \pm 0.01 & 0.09 & \pm 0 \\
4 & 0.10 & \pm 0.01 & 0.66 & \pm 0.03 & $<0.12$ & \pm 0 & 1.43 & \pm 0.07 & 0.16 & \pm 0.01 & 0.08 & \pm 0 \\
5 & 0.04 & \pm 0 & 0.13 & \pm 0.01 & $<0.12$ & \pm 0 & 0.21 & \pm 0.01 & 0.09 & \pm 0.01 & 0.03 & \pm 0 \\
\hline
\end{tabular}

Tabela 2. The concentration of heavy metals in the productions fractions of soybean oil

\begin{tabular}{|c|c|c|c|c|c|c|c|c|c|c|c|c|}
\hline \multirow{2}{*}{ Fractions } & \multicolumn{9}{|c|}{ The concentrations of heavy metals [mg/kg] } \\
\cline { 2 - 11 } & \multicolumn{2}{|c|}{$\mathrm{Cu}$} & \multicolumn{2}{|c|}{$\mathrm{Zn}$} & \multicolumn{2}{c|}{ Mn } & \multicolumn{2}{c|}{ Fe } & \multicolumn{2}{c|}{$\mathrm{Pb}$} & \multicolumn{2}{c|}{$\mathrm{Cd}$} \\
\hline 0 & 1.12 & \pm 0.04 & 19.54 & \pm 0.29 & 25.13 & \pm 0.38 & 49.71 & \pm 0.99 & 1.12 & \pm 0.06 & 0.48 & \pm 0.04 \\
1 & 0.45 & \pm 0.03 & 1.74 & \pm 0.07 & 0.97 & \pm 0.05 & 2.03 & \pm 0.11 & 0.23 & \pm 0.02 & 0.14 & \pm 0.01 \\
2 & 0.16 & \pm 0.01 & 1.41 & \pm 0.05 & 0.43 & \pm 0.03 & 0.32 & \pm 0.03 & 0.24 & \pm 0.02 & 0.15 & \pm 0.01 \\
3 & 0.08 & \pm 0 & 0.96 & \pm 0.04 & 0.17 & \pm 0.01 & 0.31 & \pm 0.03 & 0.20 & \pm 0.01 & 0.05 & \pm 0 \\
4 & 0.11 & \pm 0.01 & 0.77 & \pm 0.04 & 0.17 & \pm 0.01 & 0.39 & \pm 0.03 & 0.12 & \pm 0.01 & 0.02 & \pm 0 \\
5 & 0.05 & \pm 0 & 0.69 & \pm 0.04 & 0.15 & \pm 0.01 & 0.18 & \pm 0.01 & 0.08 & \pm 0 & 0.01 & \pm 0 \\
\hline
\end{tabular}

Tabela 3. The concentration of heavy metals in the productions fractions of linseed oil

\begin{tabular}{|c|c|c|c|c|c|c|c|c|c|c|c|c|}
\hline \multirow{3}{*}{$\begin{array}{c}\text { Fractions } \\
0\end{array}$} & \multicolumn{12}{|c|}{ The concentrations of heavy metals [mg/kg] } \\
\hline & \multicolumn{2}{|c|}{$\mathrm{Cu}$} & \multicolumn{2}{|c|}{$\mathrm{Zn}$} & \multicolumn{2}{|c|}{$\mathrm{Mn}$} & \multicolumn{2}{|c|}{$\mathrm{Fe}$} & \multicolumn{2}{|c|}{$\mathrm{Pb}$} & \multicolumn{2}{|c|}{$\mathrm{Cd}$} \\
\hline & 1.31 & \pm 0.05 & 21.23 & \pm 0.31 & 26.15 & \pm 0.41 & 59.92 & \pm 1.12 & 0.08 & \pm 0.01 & 0.65 & \pm 0.04 \\
\hline 1 & 0.67 & \pm 0.04 & 2.08 & \pm 0.09 & 1.21 & \pm 0.06 & 2.46 & \pm 0.12 & $<0.06$ & \pm 0 & 0.16 & \pm 0.01 \\
\hline 2 & 0.25 & \pm 0.02 & 0.97 & \pm 0.05 & 0.42 & \pm 0.03 & 0.27 & \pm 0.03 & $<0.06$ & \pm 0 & 0.18 & \pm 0.01 \\
\hline 3 & 0.16 & \pm 0.01 & 0.56 & \pm 0.04 & 0.14 & \pm 0.01 & 0.28 & \pm 0.03 & $<0.06$ & \pm 0 & 0.12 & \pm 0.01 \\
\hline 4 & 0.17 & \pm 0.01 & 0.60 & \pm 0.04 & 0.13 & \pm 0.01 & 0.34 & \pm 0.04 & $<0.06$ & \pm 0 & 0.13 & \pm 0.01 \\
\hline 5 & 0.10 & \pm 0.01 & 0.36 & \pm 0.03 & 0.12 & \pm 0.01 & 0.24 & \pm 0.02 & $<0.06$ & \pm 0 & 0.03 & \pm 0 \\
\hline
\end{tabular}


The final stage of oil refining, ready for the consumption, is the refined oil. The process was conducted under reduced pressure which favors the removal of metals. The $5^{\text {th }}$ fraction was characterized by the concentrations of metals below the limit of detection. They are the lowest concentrations and they are similar to those reported in literature. This fact proves good quality of the analyzed oils (Zhu et al. 2011). It is a characteristic fact that, in comparison with cold-pressed oils, a lower concentration level of each metal can be observed in the last fraction (Wroniak et al. 2006). Moreover, the concentration levels of metals such as iron, copper, lead and cadmium do not exceed admissible content specified in a relevant regulation (Minister of Health Regulation 2003).

\section{Conclusion}

The selected analytical procedure allows to obtain repeatable and accurate results relatively quickly. A similar trend in the concentration variability of the analyzed heavy metals, iron and manganese in rapeseed, linseed and soybean oil samples during production was observed. The final products are characterized by low concentrations of those heavy metals. The technology used in oil production effectively removes excessive concentrations of iron, manganese and zinc from the raw material.

\section{References}

Angelova, V., Ivanova, R. \& Ivanov, K. (2005). Heavy metal accumulation and distribution in oil crops, Communications in Soil Science and Plant Analysis, 35, pp. 2551-2566.

Corley, R.H.V.(2009). How much palm oil do we need?, Environmental Science \& Policy 2009, 12, pp. 134-139.
Domka, F., Cierpiszewski, R. \& Kłopotek, A. (2010). Metal content in rapeseed oil occuring at various stages of production, Wybrane problemy żywności, pp. 136-138. (in Polish)

Juszczak, L. (2008). Chemical contamination of food and methods of their determination, Laboratorium Przemystowe, 3, pp. 38-42. (in Polish)

Krzymański, J. (2009). Rapeseed oil - the new material, new truth, Polskie Stowarzyszenie Producentów Oleju, Warszawa 2009.

Mendila, D., Uluözlüa, O.D., Tüzena, M. \& Soylak, M. (2009). Investigation of the levels of some element in edible oil samples produced in Turkey by atomic absorption spectrometry, Journal of Hazardous Metal, 165, pp. 724-728.

Radziemska, E., Lewandowski, W., Szukalska, E., Tynek, M., Pustelnik, A. \& Ciunel, K. (2009). Biofuels in rapeseed. Preparation of raw material to obtain biodiesel in farm conditions and pilot methanolysis, Chemia, Dydaktyka, Ekologia, Metrologia, 1-2, pp. 79-84. (in Polish)

Saastamoinen, M., Pilhava, J. \& Eurola, M. (2010). Content of lignan, cadmium and some other chemical components in linseed and oil hemp varietes in south-western part of Finland, NJF Report, 6, pp. 112-115.

Szyczewski, P., Frankowski, M., Zioła-Frankowska, A., Siepak, J., Szyczewski, T. \& Piotrowski, P. (2015). Preparation of samples for the determination of heavy metals, Fe and $\mathrm{Mn}$ in vegetable oils - comparison of different extraction methods, Polish Journal of Environmental Studies, 24 (6), pp. 2947-2654.

Zhu, F., Fan, W., Wang, X., Qu, L. \& Yao, S. (2011). Health risk assessment of eight heavy metals in nine varieties of edible vegetable oils consumed in China, Food and Chemical Toxicology, 49, pp. 3081-3085.

Zioła-Frankowska, A., Frankowski, M. \& Szyczewski, P. (2011). Determination of heavy metals in vegetable oils, Laboratorium, 5-6, pp. 58-60. (in Polish)

\section{Studium porównawcze zawartości metali ciężkich w olejach: Inianym, rzepakowym i sojowym w technologicznych procesach produkcyjnych}

Streszczenie: Oleje roślinne stanowią szeroką grupę produktów stosowanych w codziennej konsumpcji. Ich produkcja i spożycie rosną kosztem bardziej szkodliwych tłuszczów zwierzęcych. Metale ciężkie stanowią zagrożenie dla zdrowia i życia ludzkiego. Przyjmuje się, że około $80 \%$ codziennej dawki dostaje się do organizmu człowiek wraz z żywnością. Stąd istnieje konieczność monitorowania ich stężeń w produktach spożywczych. Ponadto uważa się, że obecność metali ma wpływ na właściwości smakowo-zapachowe olejów, a także może przyspieszyć procesy ich jełczenia. Do analizy wybrano ziarna lnu, rzepaku i soi, są to jedne z najpopularniejszych roślin oleistych, a zarazem różnią się warunkami uprawy. Analizie poddano także ich frakcje produkcyjne i gotowy do konsumpcji produkt. Celem pracy było poznanie zmian stężeń metali ciężkich, żelaza i manganu w toku produkcyjnym. Zaobserwowano znaczące stężenia żelaza, manganu i cynku w ziarnach roślin oleistych. Stwierdzono, że proces produkcji skutecznie obniża stężenia metali do bezpiecznego poziomu w ilościach śladowych. Poziom stężeń jest zbliżony do doniesień literaturowych. 